\title{
The Role of NOL7 in All-Trans Retinoic Acid-Induced Acute Promyelocytic Leukemia Cells
}

\author{
Zeliha EMRENCE ${ }^{1}$, Melda SARIMAN ${ }^{1}$, Neslihan ABACI ${ }^{1}$, Suzan CINAR ${ }^{2}$, Burcu SALMAN ${ }^{1}$, \\ Nezahat Ece BIBEROGLU1 ${ }^{1}$, Aris CAKIRIS ${ }^{1}$, Gunnur DENIZ², Sema Sirma EKMEKCI ${ }^{1}$ \\ ${ }^{1}$ Istanbul University, Aziz Sancar Institute of Experimental Medicine, Department of Genetics \\ ${ }^{2}$ Istanbul University, Aziz Sancar Institute of Experimental Medicine, Department of Immunology, Istanbul, TURKEY
}

\begin{abstract}
The promyelocytic leukemia-retinoic acid receptor alpha (PML-RARA) fusion gene is present in 98\% of the patients with acute promyelocytic leukemia (APL), the M3 subtype of acute myeloid leukemia (AML). All-trans retinoic acid (ATRA) is widely used to treat patients with APL. Nucleolar Protein 7 (NOL7) is a tumor suppressor gene regulated by retinoid $X$ receptor (RXR). The $6 \mathrm{p} 23$ chromosomal region, where NOL7 is located, is associated with many cancers, including AML. Here, we aimed to investigate the effect of NOL7 in two AML cell lines (the PML-RARA-positive NB4 cell line and the PML-RARA-negative HL60 cell line) and in the resistance to ATRA. For this purpose, we knocked down NOL7 expression by using short interfering RNA (siRNA) and stimulated the cells with ATRA. Apoptosis, cell viability, proliferation, and granulocytic differentiation analyses were performed. Our findings show that granulocytic differentiation was blocked in ATRA-treated NB4 cells 24 hours after NOL7 siRNA transfection when the expression of NOL7 had been reduced by $81 \%$. Downregulation of NOL7 had no apparent effect on the cellular proliferation and apoptosis. Our study suggests that ATRA-induced granulocytic differentiation is inhibited in NOL7-downregulated NB4 cells. These results suggest that NOL7 expression contributes to ATRA-induced granulocytic differentiation and loss of NOL7 might be involved in the development of ATRA resistance.
\end{abstract}

Keywords: Acute myeloid leukemia, ATRA resistance, Granulocytic differentiation, NOL7, PML-RARA

ÖZET

All-Trans Retinoik Asit ile İndüklenen Akut Promiyelositik Lösemi Hücrelerinde NOL7'nin Rolü

Akut promiyelositik lösemi (APL), akut miyeloid löseminin (AML) M3 alttipi olarak sınıflandııımaktadır. APL hastalarının \%98'inde PMLRARA füzyon geni bulunmaktadır. APL tedavisinde sıklıkla all-trans retinoik asit (ATRA) kullanılmaktadır. Nükleolar Protein 7 (NOL7) geni Retinoid X Reseptör (RXR) tarafından düzenlenen tümör baskılayıcı bir gendir. 6p23 bölgesinde bulunan NOL7 geninin, AML'de dahil olmak üzere birçok kanser ile ilișkisi gösterilmiștir. Bu sebeplerle, AML hücre soylarında (PML-RARA füzyon geni bulunan NB4 ve bulunmayan HL60 hücre soylarında) NOL7 geninin etkisini ve ATRA'ya direnç gelişimindeki rolünü araştırmayı amaçladık. Bu amaçla, NB4 ve HL60 hücre soylarında NOL7 gen anlatımı short interfering RNA (siRNA) kullanılarak baskılandı ve ATRA ile uyarılı. Hücrelerde apoptoz, canlılık, proliferasyon ve granülositik farklıaşmanın analizleri yapıldı. Bulgularımıza göre, NOL7 gen anlatımının \%81 oranında baskılandığı NB4 hücrelerinde 24. saatte ATRA ile indüklenen farkllaşmanın engellendiği görüldü. NOL7 baskılanmasının hücre çoğalması ve farklılaşması üzerine bariz bir etkisi görülmedi. Bu bulgular, NB4 hücrelerinde NOL7 baskılanmasının, ATRA aracılı granülositik farklılaşmayı engellendiğini göstermiştir. Bu sonuçlar, NOL7'nin ATRA ile indüklenen granülositik farklılaşmaya katkıda bulunabileceğini ve NOL7 yokluğunun ATRA direncinin gelişiminde rol oynayabileceğini düşündürmektedir.

Anahtar Kelimeler: Akut miyeloid lösemi, ATRA direnci, Granülositik farkllaşma, NOL7, PML-RARA 


\section{INTRODUCTION}

Acute myeloid leukemia (AML), the most observed type of acute leukemia, is a cancer that affects the myeloid line of blood cells. ${ }^{1}$ AML is a heterogeneous hematological malignancy that is characterized by the accumulation of granulocyte or monocyte precursors in the bone marrow and blood, with possible spread to the liver and spleen. ${ }^{2}$ Acute promyelocytic leukemia (APL), a distinctive subtype of AML, is characterized by several possible reciprocal translocations that cause the rearrangement of the retinoic acid receptor alpha (RARA) gene. ${ }^{3}$ The most common translocation is $\mathrm{t}(15 ; 17)(\mathrm{q} 22 ; \mathrm{q} 11.2-\mathrm{q} 12)$, between chromosomes 15 and 17, involving the promyelocytic leukemia (PML) gene and RARA ${ }^{3}$; the fusion gene generated is present in more than $98 \%$ of patients with APL. ${ }^{4}$ PML-RARA fusion protein has a dominantnegative effect on wild-type RARA transcriptional activity. In addition, PML-RARA can homodimerize and can regulate genes normally not affected by RARA. The expression of PML-RARA causes the repression of terminal granulocytic differentiation and the proliferation of immature cells in the promyelocytic stage. ${ }^{5}$ Retinoic acid receptor (RAR) forms heterodimers with the retinoid $X$ receptor (RXR). The heterodimers, activated by retinoic acid (RA), bind to retinoic acid response elements (RAREs) on retinoid target genes. ${ }^{6} \mathrm{RAR} / \mathrm{RXR}$ acts as ligand-dependent transcription factors, thereby regulating the transcription of target genes. ${ }^{7}$ In the absence of RA, the RAR/RXR heterodimers recruit nuclear co-repressor proteins and suppress transcription through histone deacetylation, which causes the condensation of the chromatin. Physiologic concentrations of RA $\left(10^{-9}-10^{-8} \mathrm{M}\right)$ trigger conformational changes in the RAR/RXR heterodimer: RAR/RXR releases its co-repressors, recruits co-activators and activates transcription. However, the physiologic concentration of RA is insufficient to induce the dissociation of co-repressors from the PML-RARA fusion product in APL blasts. Therefore, pharmacological concentrations $\left(10^{-7}-10^{-6}\right.$ M) of RA are needed to activate the transcription of differentiation genes, activated by RA in physiological conditions. The treatment of APL with all-trans retinoic acid (ATRA), a synthetic form of retinoic acid (RA), is the first example of differentiation therapy of human cancer. ${ }^{8,9}$ Before the use of ATRA-based therapies, APL was the most fatal type of AML. ${ }^{10}$ ATRA is frequently combined with an anthracycline chemotherapy drug (daunorubicin or idarubicin), and sometimes with the chemotherapy drug cytarabine (ara-c) or arsenic trioxide (As2O3, AT0). ${ }^{11}$ Unfortunately, the relapse rate in AML ranges from 5 to $30 \%{ }^{12}$ and relapse and therapy resistance remain as challenges in the treatment of APL. Resistance to ATRA is a major problem, which necessitates development of new therapies. For the development of new targeted therapies in ATRA-resistance APL, it is necessary to understand the molecular mechanisms underlying the resistance to ATRA. One of the reasons for resistance may be the lack of expression of RA targeted genes.

It has been shown that the nucleolar protein 7 (NOL7) tumor suppressor gene is regulated by $\mathrm{RXR} \alpha^{13}$, suggesting that NOL7 is a RA target gene. This gene regulates angiogenesis by downregulating vascular endothelial growth factor (VEGF), a pro-angiogenic factor, and upregulating thrombospondin-1 (TSP-1), an anti-angiogenic factor. ${ }^{14,15}$ NOL7 expression is reduced in cervical carcinoma (CC) cell lines and, in tumors, the reduced expression of this gene is associated with higher relapse risk. ${ }^{16,17}$ NOL7 is located on the $6 \mathrm{p} 23$ chromosomal region, which is commonly lost in cervical cancers. Loss of the same chromosomal region is also present in other malignancies, including nasopharyngeal carcinomas, leukemias, osteosarcomas, retinoblastomas, lymphomas, and hormone refractory breast cancer. ${ }^{13,18,19}$ Furthermore, deletion of 6 p23 has been reported in therapy-related secondary AML. ${ }^{20,21}$ In the light of this information, it has been hypothesized that NOL7 may play a role as a tumor suppressor gene in APL and RARA-RXRtarget NOL7 may be related to the resistance to ATRA. However, there are no studies evaluating the role of NOL7 in APL. Therefore, we aim to investigate the effect of NOL7 on APL cell lines (the PML-RARA-positive NB4 cell line and the PML-RARA-negative HL60 cell line) and the role of NOL7 in ATRA resistance. 


\section{MATERIALS and METHODS}

\section{Cell Culture}

HL60 An 1 (Human peripheral blood promyelocytic leukemia) were obtained from the HUKUK:96041201, SAP Institute, Republic of Turkey Ministry of Agriculture and Forestry (Ankara, Turkey). NB4 cells were obtained from the Leibniz Institute DSMZ-German Collection of Microorganisms and Cell Cultures (Leibniz, Germany). Cells were grown in Iscove's Modified Dulbecco's Medium (IMDM; Lonza, Basel, Switzerland) with $10 \%$ heat-inactivated fetal bovine serum (FBS; Capricorn Scientific, Ebsdorfergrund, Germany), $100 \mathrm{mg} / \mathrm{mL}$ streptomycin, $100 \mathrm{U} / \mathrm{mL}$ penicillin (Pen/Strep; Gibco, Thermo Fisher Scientific Inc., Waltham, MA, USA) in a $5 \% \mathrm{CO}_{2}$ humidified atmosphere at $37^{\circ} \mathrm{C}$.

\section{Knockdown of NOL7 by RNA Interference and ATRA Treatment}

Exponentially growing, NB4 and HL60 cells were used for short interfering RNA (siRNA) transfection. Nucleofection was accomplished using the Amaxa instrument (Lonza) and the Cell Line Nucleofector Kit V (Lonza). siRNA (100 nM) targeting NOL7 or control (non-targeting) siRNA (Flexitube siRNA, Qiagen GmbH, Hilden, Germany) were used. Non-transfected cells and control siRNA-transfected cells were used as negative controls. Each siRNA treatment was performed in triplicate. After transfection, $1 \mu \mathrm{M}$ ATRA (Sigma Aldrich, Hamburg, Germany; stock, $10 \mathrm{mM}$ in ethanol was added to the cell cultures. At 24, 48, $72 \mathrm{~h}$ after transfection, the cells were harvested.

\section{NOL7 Expression Analysis}

Validation of knockdown was confirmed by qRTPCR. Total RNA was extracted from cells using the RNeasy Mini Kit (Qiagen) following the manufacturer's recommendations. Reverse transcription was performed using random hexamers and the Transcriptor First Strand cDNA Synthesis Kit (Roche Life Science, Mannheim, Germany) following the manufacturer's manual RNA samples and random hexamers were heated to $65^{\circ} \mathrm{C}$ for 5 minutes for denaturation. The reactions were cooled on ice and the remaining reagents $(5 \times$ reac- tion buffer, RNase inhibitor, dNTPs, Reverse Transcriptase) were added as specified in the protocol and the reaction proceeded for $10 \mathrm{~min}$ at $29^{\circ} \mathrm{C}$ and 1 hour at $48^{\circ} \mathrm{C}$. Finally, the reaction was inactivated by a $5 \mathrm{~min}$ incubation at $85^{\circ} \mathrm{C}$. qRT-PCR was performed using the LightCycler 480 SYBR Green I Mix (Roche Diagnostic, Mannheim, Germany) and the LightCycler 480 Instrument II (Roche Diagnostic, Mannheim, Germany), using the following PCR conditions: $95^{\circ} \mathrm{C}$ for $5 \mathrm{~min}$, and 45 cycles of $95^{\circ} \mathrm{C}$ for 20 seconds, $61^{\circ} \mathrm{C}$ for 20 seconds, and $72^{\circ} \mathrm{C}$ for 15 seconds. After amplification, the program for melting curve analysis was applied at $95^{\circ} \mathrm{C}$ for 1 second, 10 seconds at $50^{\circ} \mathrm{C}$ for 10 seconds and at $95^{\circ} \mathrm{C}$ for 1 second ( 1 cycle). TATA binding protein (TBP) was used as control gene. Forward and reverse primers were $\left(5^{\prime}-3^{\prime}\right)$ as follows: TBP forward, ACT TGA CCT AAA GAC CAT TGC AC and TBP reverse, CTT GAA GTC CAA GAA CTT AGC TGG; NOL7 forward: ACA TCA AGA AAT CGC CAG GAA AGG, and NOL7 reverse: GCT GCT TGT TGC CTT GAA TCT C. Serial dilutions were prepared for the standards. All qRT-PCR reactions were conducted in triplicate. The mean value of the replicates for each sample was calculated. Quantification was performed using the relative standard curve method. ${ }^{22}$ Expression of NOL7 was normalized against that of the housekeeping gene TBP. Each experiment was performed in triplicate.

\section{CD11b Expression Analysis}

Granulocytic differentiation of the cells was determined by evaluating the expression of the surface CD11b antigen by flow cytometry. Cells $\left(1 \times 10^{6}\right)$ were collected and incubated with fluorescein isothiocyanate (FITC) mouse anti-human CD11b/ MAC-1 antibody (Becton Dickinson, Heidelberg, Germany). Cytometry was performed using a FACSCalibur flow cytometer (Becton Dickinson, Heidelberg, Germany). The percentage of positive cells was quantitated using the CellQuest Pro software (Becton Dickinson, Heidelberg, Germany). At least 200.000 cells were analyzed for each data point.

\section{Apoptosis Assays}

The percentage of apoptotic cells was determined using a Phycoerythrin (PE) Annexin V Apoptosis 

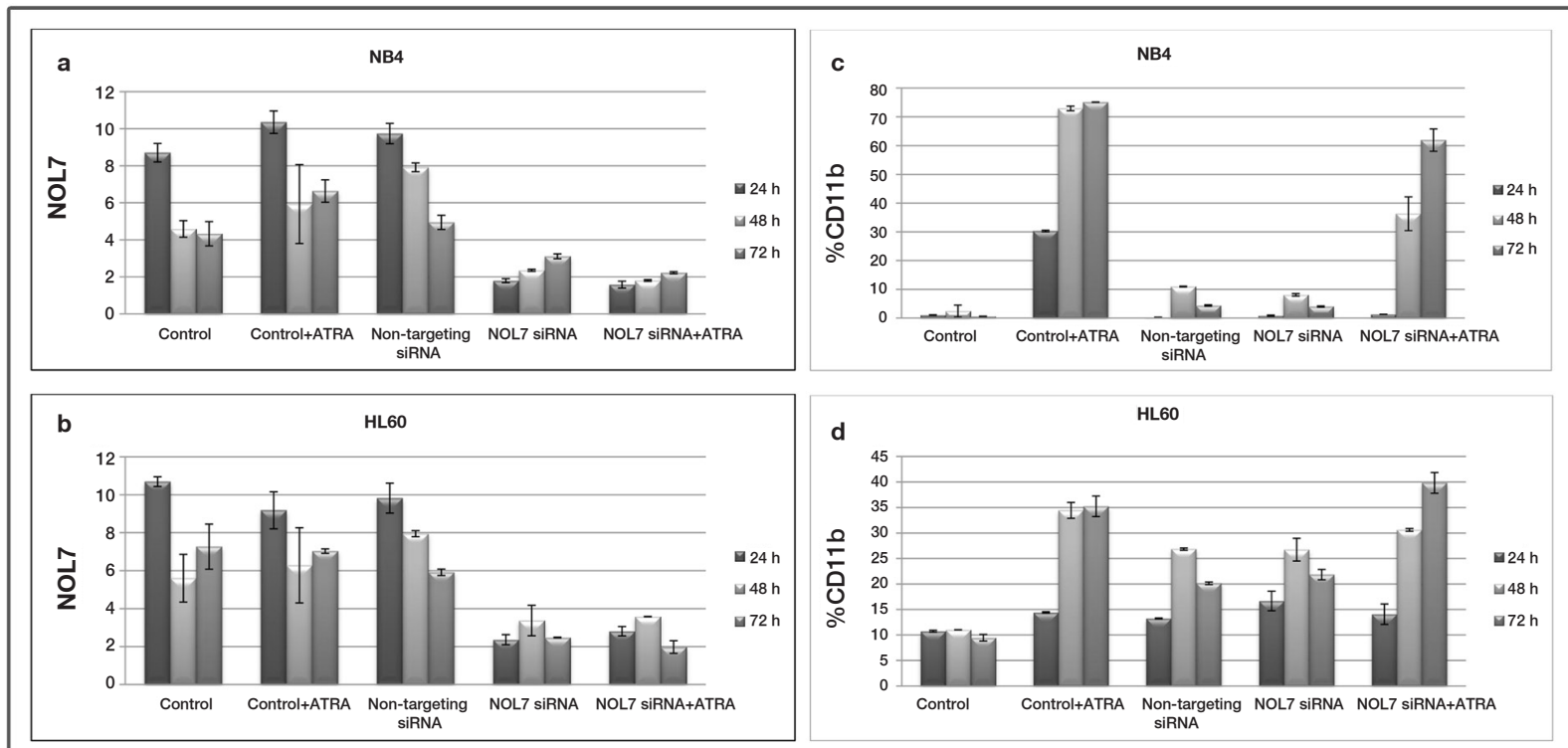

Figure 1. Expression of NOL7 and CD11b in NB4 and HL60 cells after transfection of short interfering RNA (siRNA) targeting NOL7 and/or all-trans retinoic acid (ATRA) treatment. Expression levels of NOL7 were detected 24, 48 and 72 hours (h) after transfection by quantitative PCR in NB4 (a) an HL60, (b) cell lines. Expression of CD11b in NB4 (c) and HL60, (d) cells. The surface expression of CD11b, a marker of granulocytic differentiation, was examined 24, 48 and 72 hours (h) after transfection by flow cytometry.

Control= Untreated Cells; Control + ATRA= Cells were stimulated with $1 \mu \mathrm{M}$ ATRA; NT siRNA= Cells were transfected with non-targeting siRNA; NOL7 siRNA= Cells were transfected with siRNA targeting NOL7; NOL7 siRNA +ATRA=Cells were transfected with siRNA targeting NOL7 and stimulated with 1 MM ATRA

Detection Kit I (Becton Dickinson, Heidelberg, Germany). and a FACSCalibur (Becton Dickinson, Heidelberg, Germany), in accordance with the manufacturer's protocol. The percentage of positive cells was quantitated using the CellQuest Pro software (Becton Dickinson, Heidelberg, Germany). At least 200.000 cells were analyzed for each data point.

\section{In-vitro Growth Curve}

For growth curve analysis, cell number and cell viability were determined by counting the cells after trypan blue exclusion using the Vi-Cell Cell Counter and Cell Viability Analyzer (Beckman Coulter, Brea, CA, USA) at 24, 48, $72 \mathrm{~h}$ after the indicated treatments.

\section{Proliferation Assays}

Cell proliferation was assessed using a 3-(4,5-dimethylthiazol-2-yl)-2,5-diphenyltetrazolium bromide (MTT, Sigma-Aldrich, Ireland Ltd., Wicklow, Ireland) assay. MTT (final concentration, $0.5 \mathrm{mg} / \mathrm{mL}$ in PBS) was added to each well and incubated for $3 \mathrm{~h} .{ }^{23}$ Afterwards, we centrifuged the plate at $420 \mathrm{~g}$ for $5 \mathrm{~min}$ at $4^{\circ} \mathrm{C}$. Next, $80 \mu \mathrm{L}$ dimethyl sulfoxide (DMSO) were added, to solubilize the dark-blue formazan crystals. Absorbance in each well was measured at $570 \mathrm{~nm}$, using the Multiskan Spectrum instrument (Thermo Electron Corporation, Beverly, MA, USA). All assays were performed in quadruplicates. Results are reported as the mean \pm the standard deviation.

\section{Statistical Analysis}

Statistical analysis was performed using Student's T test to determine any statistically significant difference in CD11b levels. The Statistical Package for Social Sciences (SPSS version 17.0, SPSS Inc, Chicago, IL, USA) was used for all data analyses. The statistical significance was accepted at $\mathrm{p}<0.05$.

\section{RESULTS}

\section{Efficiency of NOL7 silencing in NB4 and HL60 Cells}

We first transfected NB4 and HL60 cells with NOL7 siRNA and treated them with ATRA. The 


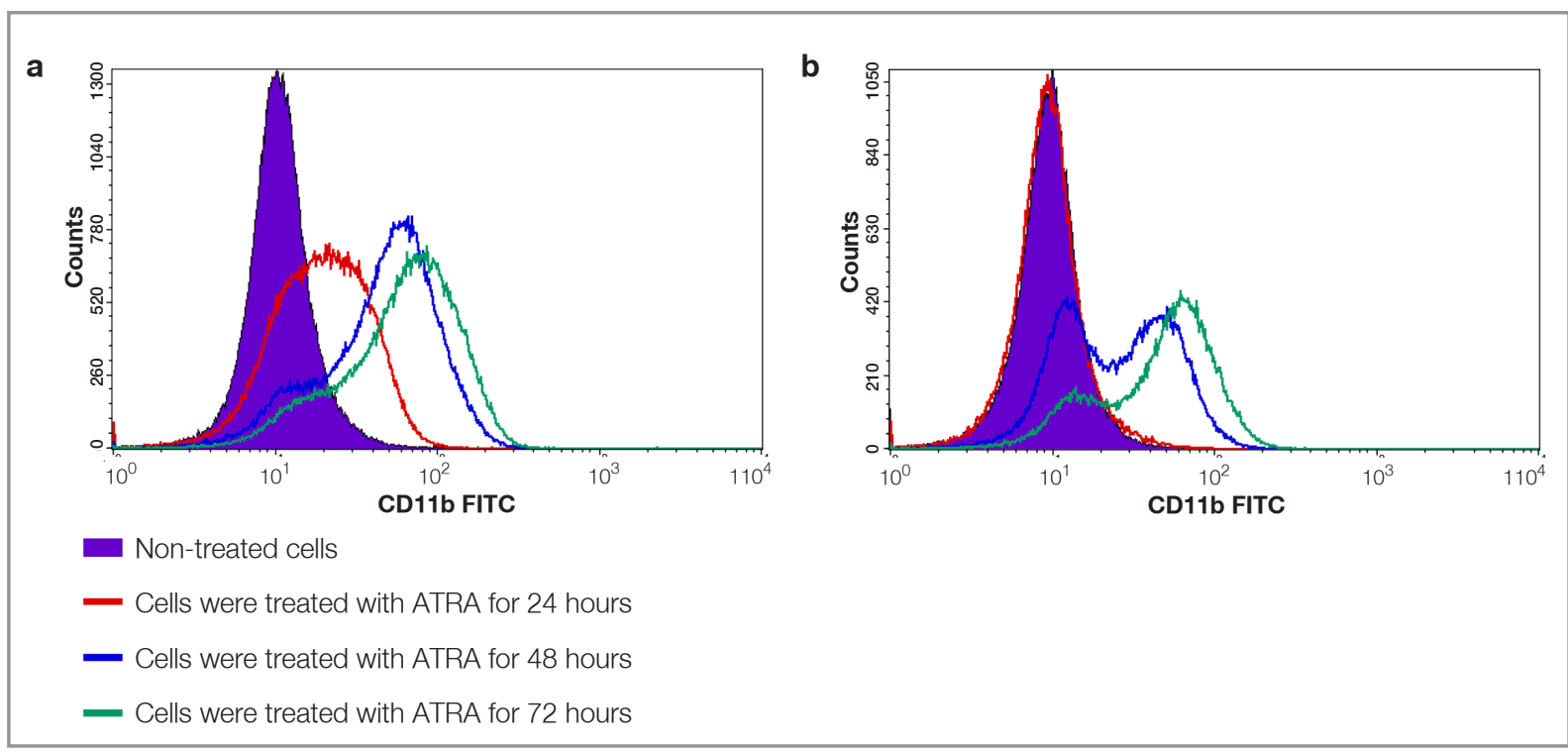

Figure 2. Histograms represent CD11b expression in NB4 and HL60 cells after incubation with ATRA for 24/48/72 hours. Expression of CD11b was analyzed by fow cytometry. (a) CD11b expression ATRA-treated NB4 cells and control NB4 cells. (b) CD11b expression ATRA-treated NOL7 downregulated NB4 cells and control NB4 cells

cells were cultured for 24,48 , or $72 \mathrm{~h}$ and then harvested. qRT-PCR was used to determine the knockdown level of NOL7. We found that NOL7 expression was downregulated by $81.6 \%, 70.2 \%$, $37.1 \%$, respectively, 24,48 and $72 \mathrm{~h}$ after transfection in NB4 cells (Figure 1a; NOL7 expression bars, compare each time point in non-targeting siRNA and NOL7 siRNA). On the other hand, NOL7 expression was downregulated by $75.9 \%, 57.5 \%$, $58 \%$, respectively, at 24, 48 and $72 \mathrm{~h}$ in HL60 cells (Figure 1b; NOL7 expression bars, compare each time point in non-targeting siRNA and NOL7 siRNA).

\section{Effect of NOL7 Knockdown on ATRA-Induced Differentiation}

We examined the surface expression of CD11b, a marker of granulocytic differentiation, in NB4 and HL60 cells silenced by NOL7 siRNA and/or treated with ATRA $(1 \mu \mathrm{M})$. Samples were collected at 24,48 , and $72 \mathrm{~h}$, and analyzed by flow cytometry, after staining with an anti-CD11b antibody. CD11b expression gradually increased over time in ATRA-treated cells (Figure 2a and 2b). This effect was observed in both NB4 and HL60 cells, but it was stronger in NB4 cells (Figure 2a). Granulocytic differentiation was blocked in ATRA-

UHOD Number: 2 Volume: 30 Year: 2020 treated NB4 cells 24 hours after NOL7 siRNA transfection (Figure 1c; Control+ATRA and NOL7 siRNA+ATRA bars, $\mathrm{p}<0.0001$ ), when the expression of NOL7 had been reduced by $81 \%$ (Figure 1a Control+ATRA and NOL7 siRNA+ATRA bars). Forty-eight hours after RNA interference, when the levels of NOL7 were approximately $30 \%$ of control, CD11b levels were reduced to about $50 \%$ of the control after ATRA treatment (Figure 1a and 1c; compare NOL7 siRNA bars and NOL7 siRNA + ATRA bars). Seventy-two hours after transfection, while NOL7 levels were $63 \%$ of control, it was observed that CD11b levels further increased, though they were lower than in control cells treated with ATRA (Figure 1a and 1c; compare NOL7 siRNA + ATRA with Control + ATRA). Interestingly, CD11b expression did not significantly change in ATRA-treated HL60 cells silenced by NOL7 siRNA (Figure 1b and 1d; compare Control + ATRA and NOL7 siRNA + ATRA bars, at each time point). Importantly, HL60 cells do not have the PML-RARA fusion gene.

\section{Effect of NOL7 Knockdown on Cell Prolifera- tion and Apoptosis}

We then investigated the proliferation and apoptosis of the cells upon NOL7 knockdown and ATRA treatment. At the different time points $(24,48$ and 
$72 \mathrm{~h}$ ), the growth curve of ATRA-treated cells was similar to that of control (untreated cells) in NB4 cells $(p=0.42$ for $24 h, p=0.53$ for $48 h$ and $p=$ $0.71)$ and HL60 cells ( $p=0.96$ for $24 \mathrm{~h}, \mathrm{p}=0.49$ for $48 \mathrm{~h}$ and $\mathrm{p}=0.53$ for $72 \mathrm{~h}$. Apoptosis assays showed that there was no significant difference between control NB4 and ATRA-treated NB4 cells $(\mathrm{p}=0.12$ for $24 \mathrm{~h}, \mathrm{p}=0.21$ for $48 \mathrm{~h}$ and $\mathrm{p}=0.53$ for $72 \mathrm{~h}$ ). There was not significant difference between control HL60 and ATRA-treated HL60 cells $(\mathrm{p}=0.72$ for $24 \mathrm{~h}, \mathrm{p}=0.11$ for $48 \mathrm{~h}$ and $\mathrm{p}=0.27$ for $72 \mathrm{~h})$. Apoptosis was increased in both cell lines upon transfection with NOL7 or non-targeting siRNA. Apoptosis was not significantly different between NOL7 siRNA+ATRA and control+ATRAtreated NB4 cells $(p=0.59$ for $24 \mathrm{~h}, \mathrm{p}=0.94$ for $48 \mathrm{~h}$ and $\mathrm{p}=0.14$ for $72 \mathrm{~h}$ ) and HL60 cells ( $\mathrm{p}=$ 0.31 for $24 \mathrm{~h}, \mathrm{p}=0.49$ for $48 \mathrm{~h}$ and $\mathrm{p}=0.98$ for 72 h). Additionally, proliferation assays showed that there was no significant difference between control and ATRA-treated NB4 cells at 24h and $48 \mathrm{~h}$ $(p=0.32$ and $p=0.73$ respectively). Proliferation increased in ATRA-treated NB4 cells compare to control at $72 \mathrm{~h}(\mathrm{p}=0.002)$. In HL60 cells, proliferation slightly increased in ATRA treated cells compare to control at $48 \mathrm{~h}$ and $72 \mathrm{~h}(\mathrm{p}=0.014$ and $\mathrm{p}=0.032$ respectively) and was not different at $48 \mathrm{~h}(\mathrm{p}=0.50)$. Similar results were observed when we investigated the proliferation of the cells: we found decreased proliferation in SiRNA transfected cells (NOL7 and non-targeting siRNA) by MTT assays and cell count over time using trypan blue. There was not significant difference between NOL7 siRNA+ATRA and control+ATRA-treated NB4 cells ( $\mathrm{p}=0,06$ for $24 \mathrm{~h}, \mathrm{p}=0.06$ for $48 \mathrm{~h}$ and $p=0.07$ for $72 \mathrm{~h}$ ) and HL60 cells ( $p=0.22$ for $24 \mathrm{~h}$, $p=0.86$ for $48 \mathrm{~h}$ and $\mathrm{p}=0.53$ for $72 \mathrm{~h}$ ). Cell count also was not significantly different between NOL7 siRNA+ATRA and control+ATRA-treated NB4 cells $(p=0.21$ for $24 \mathrm{~h}, \mathrm{p}=0.15$ for $48 \mathrm{~h}$ and $\mathrm{p}=$ 0.36 for $72 \mathrm{~h}$ ) and HL60 cells ( $\mathrm{p}=0.16$ for $24 \mathrm{~h}, \mathrm{p}=$ 0.56 for $48 \mathrm{~h}$ and $\mathrm{p}=0.36$ for $72 \mathrm{~h}$ ).

\section{DISCUSSION}

Abnormal proliferation and inhibition of the differentiation of immature cells in the promyelocytic stage of hematopoiesis is characteristic of APL, a fatal disease, if not treated properly. ${ }^{10} 98 \%$ of the patients have a reciprocal translocation between RARA on chromosome 15 and PML on chromosome $17 .{ }^{24}$ The expression of the PML-RARA fusion gene inhibits terminal myeloid differentiation in APL. ${ }^{24}$ ATRA-based therapy in patients with APL is the first example of a treatment that fights cancer by stimulating cell differentiation. ${ }^{25}$ Specifically, in vitro and in vivo studies have proven that ATRA treatment induces the differentiation of immature promyelocytic cells to granulocytes. ${ }^{26} \mathrm{De}$ spite the high success of ATRA treatment, 5-30\% of patients with APL relapse. ${ }^{27}$ In addition, differentiation syndrome (DS), formerly known as retinoic acid syndrome, is observed in APL patients between $2 \%$ and $48 \%{ }^{28}$ This syndrome is characterized by unexplained fever and hypotension, weight gain $>5 \mathrm{~kg}$, acute respiratory distress with the interstitial pulmonary infiltrates and acute renal failure. ${ }^{29}$ Patients with differentiation syndrome have an increased risk of relapse. ${ }^{30}$

The loss of the $6 \mathrm{p} 23$ chromosomal region has been reported in lymphomas, osteosarcomas, retinoblastoma, nasopharyngeal carcinomas, cervical cancers, hormone refractory breast cancer, and leukemias, including APL. ${ }^{13}$ NOL7, a target gene for RXR, is a tumor suppressor gene located on the short arm of chromosome 6 (at 6p23). ${ }^{13,15}$ The tumor suppressor function of NOL7 has been discovered in recent years and few studies ${ }^{13,18}$, have investigated the mechanism of NOL7 function. Although its function is not clear yet, reduced NOL7 expression is associated with relapse risk in cervical cancer ${ }^{17}$ To our knowledge, there is no study on NOL7 in hematological malignancies.

Myeloid differentiation is regulated by extrinsic (hematopoietic cytokines and growth factors) and intrinsic (transcription factors) factors. RAR target genes also play a role in myeloid differentiation. ${ }^{6}$ It has been showed that NOL7 is a target gene for RXR, heterodimerizes with RAR. ${ }^{13}$ In this study, we aimed to investigate the effect of NOL7 silencing in response to ATRA in AML cell lines. Specifically, we induced granulocytic differentiation using $1 \mu \mathrm{M}$ of ATRA in NB4 and HL60 cells for 24, 48 and 72 hours, as described in other studies in the literature..$^{25}$ We used HL60, an AML cell line without the $\mathrm{t}(15 ; 17)$ translocation and the PMLRARA fusion gene, and NB4, an APL cell line with 
the $t(15 ; 17)$ translocation. Although HL60 called promyelocytic leukemia, reevaluation of original patient's sample indicated that it is an acute myeloblastic leukemia cell line (M2) ${ }^{26}$ RA treatment of these cells resulted in increased terminal myeloid differentiation, according to previous studies. ${ }^{5,25}$

We showed that the viability of the cells decreased upon transfection of NB4 and HL60 cells with NOL7 and non-targeting siRNA compared with control (non-transfected) cells. Electroporation is decrease cell proliferation as it has been observed in other studies in the literature. ${ }^{31}$ Similarly, we found increased apoptosis and decreased proliferation in the two cell lines upon transfection of siRNA. With the exception of some cell types, the decrease of metabolic activity is an inevitable result of electroporation. ${ }^{31}$

We investigated the expression of the differentiation marker CD11b by flow cytometry. In control cells, ATRA treatment was associated with increased CD11b expression, especially after 48 and $72 \mathrm{~h}$ of treatment $(\mathrm{p}<0.01)$. Granulocytic differentiation was inhibited in ATRA-treated NB4 cells in which NOL7 had been silenced: the effect of NOL7 silencing was the strongest $24 \mathrm{~h}$ after transfection, when the expression of NOL7 had been reduced by $81 \%$, and progressively diminished as the knockdown of NOL7 decreased. These findings, which have not been reported previously in the literature, indicate that NOL7 plays an important role on ATRA-induced granulocytic differentiation. On the other hand, we showed that downregulation of NOL7 did not affect ATRA-induced differentiation in HL60 cells: indeed, we did not observe any difference in CD11b levels by comparing ATRA-treated cells with ATRA-treated and NOL7-silenced cells. Because HL60 cells do not have the PML-RARA fusion gene, this result suggests that the effect of NOL7 knockdown on the differentiation of APL cells depend on presence of PML-RARA. PML-RARA fusion protein behaves as potent transcriptional repressors of retinoic acid signalling, inducing a differentiation blockage at the promyelocyte stage which can be overcome with therapeutic doses of ATRA. Our result suggested that NOL7 play important role in reversal of PML-RARA-induced differentiation blockage with ATRA.
The DS has problems in treatment since the pathogenesis of the DS is complex and not fully understood. It is critical to recognize the initial signs and symptoms of DS and respond to it quickly, wherefore delay in diagnosis can lead to severe, even life-threatening complications. ${ }^{28,29}$ Differentiation of blast cells by ATRA cause the release of cytokines like pro-inflammatory cytokines, including interleukin 1 beta (IL1B), IL6, IL8 and tumour necrosis factor alpha (TNFa). As a result, systemic inflammatory response syndrome (SIRS) occurs. ${ }^{32}$ The release of cathepsin $G$ results in increasing vascular permeability and endothelial damage. ${ }^{33}$ NOL7 can lead to differentiation syndrome with regulation of angiogenesis via downregulating a pro-angiogenic factor VEGF and upregulating an anti-angiogenic factor TSP-1. ${ }^{14,15}$ The role of NOL7 gene APL DS should be analysed.

One of the mechanisms of ATRA resistance is the loss in or absent expression of tumor suppressor genes targeted by RA. The effect of NOL7 in the NB4 cell line can be explained by this mechanism. A study by Doçi et al. has shown that in cervical cancers there is a relation between loss of NOL7 gene expression and relapse. ${ }^{16}$ In this study, we demonstrated that ATRA-induced granulocytic differentiation of NB4 cells is inhibited by knockdown of NOL7. Furthermore, this study contributes to understand the mechanism of ATRA-induced granulocytic differentiation. However, additional studies are necessary to understand the full mechanism of NOL7 action.

\section{Conclusion}

NOL7 downregulation prevents ATRA-induced granulocytic differentiation in NB4 cells (APL cells with the PML-RARA fusion gene). Our study shows that loss of NOL7 function leads to ATRA resistance in APL cells with the PML-RARA fusion and restoring NOL7 by targeting its epigenetic and transcriptional regulators which could be beneficial for the treatment of patients showing resistance to ATRA.

\section{Acknowledgements}

This work was supported by the [Scientific Research Projects Coordination Unit of Istanbul University] under Grant [number 25887]. 
International Journal of Hematology and Oncology

\section{REFERENCES}

1. De Kouchkovsky I, Abdul-Hay M. Acute myeloid leukemia. A comprehensive review and 2016 update'. Blood Cancer J 6: e441, 2016.

2. Tenen DG. Disruption of differentiation in human cancer. AML shows the way. Nat Rev Cancer 3: 89-101, 2003.

3. He LZ, Guidez F, Tribioli C, et al. Distinct interactions of PMLRARalpha and PLZF-RARalpha with co-repressors determine differential responses to RA in APL. Nat Genet 18: 126-135, 1998.

4. Vitoux D, Nasr R, de The H. Acute promyelocytic leukemia: New issues on pathogenesis and treatment response. Int $\mathrm{J}$ Biochem Cell Biol 39: 1063-1070, 2007.

5. Pitha-Rowe I, Petty WJ, Kitareewan S, Dmitrovsky E. Retinoid target genes in acute promyelocytic leukemia. Leukemia 17: 1723-1730, 1998.

6. Minucci S, Leid M, Toyama R, et al. Retinoid X receptor (RXR) within the RXR-retinoic acid receptor heterodimer binds its ligand and enhances retinoid-dependent gene expression. Mol Cell Biol 17: 644-655, 1997.

7. Zhang R, Wang Y, Li R and Chen G. Transcriptional Factors Mediating Retinoic Acid Signals in the Control of Energy Metabolism. Int J Mol Sci 16: 14210-14244, 2015.

8. Moosavi MA, Djavaheri-Mergny M. Autophagy: New Insights into Mechanisms of Action and Resistance of Treatment in Acute Promyelocytic leukemia. Int J Mol Sci 20: 3559, 2019.

9. Lauren P. Molecular Biology of Cancer: Mechanisms, Targets, and Therapeutics. 3rd edition. Oxford University Press, United Kingdom, 2012: 187-188.

10. Ohno R, Asou N, Ohnishi K. Treatment of acute promyelocytic leukemia: Strategy toward further increase of cure rate. Leukemia 17: 1454-1463, 2003.

11. Long ZJ, Hu Y, Li XD, et al. ATO/ATRA/anthracycline-chemotherapy sequential consolidation achieves long-term efficacy in primary acute promyelocytic leukemia. PLoS One 9: e104610, 2014.

12. Tallman MS. Treatment of relapsed or refractory acute promyelocytic leukemia. Best Pract Res Clin Haematol 20: 5765, 2007.

13. Mankame TP, Zhou G, Lingen MW. Identification and characterization of the human NOL7 gene promoter. Gene 456: 36-44, 2010.

14. Hasina R, Pontier AL, Fekete MJ, et al. NOL7 is a nucleolar candidate tumor suppressor gene in cervical cancer that modulates the angiogenic phenotype. Oncogene 25: 588598, 2006.

15. Doçi CL, Zhou G, Lingen MW. The novel tumor suppressor NOL7 post-transcriptionally regulates thrombospondin-1 expression. Oncogene 32: 4377-4386, 2013.
16. Doçi CL, Mankame TP, Langerman A, et al. Characterization of NOL7 gene point mutations, promoter methylation, and protein expression in cervical cancer. Int J Gynecol Pathol 31: 15-24, 2012.

17. Huang L, Zheng M, Zhou Q-M, et al. Identification of a 7-gene signature that predicts relapse and survival for early stage patients with cervical carcinoma. Med Oncol 29: 2911-2918, 2012.

18. Kinor N, Shav-Tal $\mathrm{Y}$. The dynamics of the alternatively spliced NOL7 gene products and role in nucleolar architecture. Nucleus 2: 229-245, 2011.

19. Chen Z, Issa B, Brothman LJ, et al. Nonrandom rearrangements of $6 p$ in malignant hematological disorders. Cancer Genet Cytogenet 121: 22-25, 2000.

20. Nakase K, Wakita Y, Minamikawa K, et al. Acute promyelocytic leukemia with del(6)(p23). Leuk Res 24: 79-81, 2000.

21. Anwar lqbal M, Al-Omar HM, Owaidah T, et al. del(6)(p23) in two cases of de novo AML- a new recurrent primary chromosome abnormality. Eur J Haematol 77: 245-250,2006.

22. Pfaffl MW. A new mathematical model for relative quantification in real-time RT-PCR. Nucleic Acids Res 29: e45, 2001.

23. Van de Loosdrecht AA, Beelen RH, Ossenkoppele GJ, et al. A tetrazolium-based colorimetric MTT assay to quantitate human monocyte mediated cytotoxicity against leukemic cells from cell lines and patients with acute myeloid leukemia. J Immunol Methods 174: 311-320, 1994.

24. Chen Z, Brand NJ, Chen A, et al. Fusion between a novel Krüppel-like zinc finger gene and the retinoic acid receptoralpha locus due to a variant $\mathrm{t}(11 ; 17)$ translocation associated with acute promyelocytic leukaemia. EMBO J 12: 1161 $1167,1993$.

25. Tallman MS, Andersen JW, Schiffer CA, et al. All-trans retinoic acid in acute promyelocytic leukemia: Long-term outcome and prognostic factor analysis from the North American Intergroup protocol. Blood 100: 4298-4302, 2002.

26. Ozpolat B, Akar U, Steiner M, et al. Programmed cell death-4 tumor suppressor protein contributes to retinoic acid-induced terminal granulocytic differentiation of human myeloid leukemia cells. Mol Cancer Res 5: 95-108, 2007.

27. Ozpolat B. Acute promyelocytic leukemia and differentiation therapy: Molecular mechanisms of differentiation, retinoic acid resistance and novel treatments. Turk J Haematol 26: 47-61, 2009.

28. Stahl M, Tallman M.S. Differentiation syndrome in acute promyelocytic leukaemia. Br J Haematol 187: 157-162, 2019.

29. Montesinos P, Sanz M.A. The differentiation syndrome in patients with acute promyelocytic leukemia: Experience of the pethema group and review of the literature. Mediterr $\mathrm{J} \mathrm{He}$ matol Infect Dis 3: e2011059, 2011.

30. Denu RA, Henrich Lobo R, Mattison RJ. Management of dif- 
ferentiation syndrome in an elderly patient with acute promyelocytic leukemia who subsequently developed refractory anemia with ring sideroblasts. Leuk Lymphoma 57: 2905-2907, 2016.

31. Lanotte M, Martin-Thouvenin V, Najman S, et al. NB4, a maturation inducible cell line with $\mathrm{t}(15 ; 17)$ marker isolated from a human acute promyelocytic leukemia (M3). Blood 77: 10801086, 1991.

32. Dubois $\mathrm{C}$, Schlageter $\mathrm{MH}$, de Gentile A, et al. Hematopoietic growth factor expression and ATRA sensitivity in acute promyelocytic blast cells. Blood 83: 3264-3270, 1994.

33. Seale J, Delva L, Renesto P, et al. All-trans retinoic acid rapidly decreases cathepsin $\mathrm{G}$ synthesis and mRNA expression in acute promyelocytic leukemia. Leukemia 10: 95-101, 1996.

\section{Correspondence:}

Sema Sirma-Ekmekci, Ph.D.

Istanbul Universitesi

Aziz Sancar Deneysel Tip Arastirma Enstitüsü

Genetik Anabilim Dali

Vakif Gureba Caddesi

34093 Fatih, ISTANBUL / TURKEY

Tel: (+90-212) 4142000 / 33316

Fax: (+90-212) 5324171

e-mail: sirmasem@istanbul.edu.tr

\section{ORCIDs:}

Zeliha Emrence:

0000-0003-4809-6366

Melda Sariman:

0000-0003-0898-529x

Neslihan Abaci:

$0000-0002-9962-4010$

Suzan Cinar:

0000-0002-8330-7010

Burcu Salman:

0000-0002-9144-3899

Nezahat Ece Biberoglu:

0000-0002-8554-9574

Aris Cakiris:

0000-0002-6614-9620

Gunnur Deniz:

$0000-0002-0721-6213$

Sema Sirma Ekmekci:

0000-0002-1201-7542 